\title{
Near-surface seismic refraction tomography and MASW for site characterization in Phuentsholing, Bhutan Himalaya
}

\author{
Raju Sarkar $^{1} \cdot$ Sreevalsa Kolathayar ${ }^{2}$ (D) Dowchu Drukpa ${ }^{3} \cdot$ Kinley Choki $^{4} \cdot$ Shrijana Rai $^{4} \cdot$ Sangay Tenzin Tshering ${ }^{4}$. \\ Kezang Yuden ${ }^{4}$
}

Received: 7 October 2020 / Accepted: 6 February 2021 / Published online: 1 March 2021

(c) The Author(s) $2021 \quad$ OPEN

\begin{abstract}
It is essential to understand the soil characteristics of the subsurface layers for any engineering construction. In difficult terrains like hilly areas, conventional methods of investigation are expensive and difficult to conduct. It calls for nondestructive testing methods to get reliable estimates of subsurface properties. In the present study, seismic refraction tomography (SRT) technique and multichannel analysis of surface waves (MASW) methods were carried out along five selected profiles in Phuentsholing region of Bhutan Himalaya. The profile length ranges from 37 to $81.5 \mathrm{~m}$, and depth of imaging down to $10 \mathrm{~m}$. While the SRT data imaged the P-wave velocity $\left(V_{\mathrm{p}}\right)$ structures, the MASW imaged the shear wave velocity $\left(V_{s}\right)$ structures. The P-wave images provide a fair knowledge of geological layers, while the MASW images provide S-wave velocity structures $\left(V_{s}\right)$. These results are useful to estimate soil parameters, like the density, Poisson's ratio, Young's modulus, shear modulus, $\mathrm{N}$-value and the ultimate bearing capacity. The seismic images reveal the presence of sand, sandy clay, gravels and shale layers below the selected sites. Bhutan Himalayas being seismically vulnerable, the obtained results in terms of shear wave velocity were accustomed to categorize the sites as per NEHRP site classes, and a ground response analysis was performed to determine the reliable amplification factors. From the study, it is suggested that the engineering construction is feasible at all the sites except in one site, where an indication of saturated soil is observed which is vulnerable for liquefaction, and ground needs to be improved before construction at that site.
\end{abstract}

Keywords Seismic refraction tomography $\cdot$ MASW $\cdot$ Primary and shear wave velocity $\cdot$ Soil profile $\cdot$ Site class

\section{Introduction}

Before commencement of any engineering construction, it is important to check soil profiles and soil characteristics in order to ensure that the site is acceptable for making such construction. In Bhutan Himalaya, the terrain poses difficulties in conducting conventional soil investigations using shell and auger, open-pit, etc. These methods are noneconomic and take time to perform. The conventional methods, viz. cone penetration test (CPT), provide required parameters of the soil but are costly and invasive, particularly in hilly terrains [16]. Seismic refraction tomography technique (SRT) as well as the multichannel analysis of surface waves (MASW), on the other hand, is time efficient and cost effective. Seismic refraction tomography (SRT) provides velocity structure and the required soil parameters without disturbing the natural ground condition $[2,5,18,25]$. Over the past years, seismic refraction methods have been used for civil engineering purposes in mountainous terrain [10,14,28]. They have been used to locate faults and in determining the soil parameters [4, 16]. The SRT is a geophysical method which uses inversion

$\triangle$ Sreevalsa Kolathayar, sreevalsa@nitk.edu.in | ${ }^{1}$ Department of Civil Engineering, Delhi Technological University, Bawana Road, Delhi, India. ${ }^{2}$ Department of Civil Engineering, National Institute of Technology, Surathkal, India. ${ }^{3}$ Department of Geology and Mines, Ministry of Economic Affairs, Thimphu, Bhutan. ${ }^{4}$ Department of Civil Engineering and Architecture, College of Science and Technology, Phuentsholing, Bhutan. 
technique to obtain $2 \mathrm{D}$ velocity depth profile $[17,22,23]$ that images the cross-sectional picture along the profile by using the soils' response to the energy from the external source $[6,7,11]$.

The multichannel analysis of surface waves (MASW) is a method used to estimate the shear wave velocity at a shallow depth and also help to determine the elastic parameters of the soil $[14,30]$. The SRT and MASW data are used for estimating seismic velocities and elastic parameters which are needed to estimate the bearing capacity of the soil mass and for the design of structures which is going to be constructed over it [15]. The damages due to seismic activity are controlled by local geology and soil parameters in addition to construction characteristics of structures. Seismic ground response at a particular location is strongly affected by in situ conditions of local geology and soil characteristics [19-21]. The soil condition has an important effect on the ground vibration. This gives the attention toward the importance of site classification in seismically vulnerable areas. Seismic site enactment due to shear wave velocity will indicate the mechanics of site amplification. The geophysical methods are seen as the most reliable for seismic site characterization $[2,26]$. This paper focuses on site characterization at five locations at Phuentsholing in Bhutan Himalayas using the SRT and MASW to assess the feasibility of engineering constructions and to classify the sites as per NEHRP site classification.

\section{Study area}

Bhutan is a small kingdom located in the eastern Himalayas, nestling between India and China with a total area coverage of $38,394 \mathrm{~km}^{2}$ (Fig. 1). Our study areas are located in Phuentsholing Gewog under Chukha Dzongkhag covering an area of $15.6 \mathrm{~km}^{2}$ with an average elevation of $293 \mathrm{~m}$ which serves as the administrative seat of the Dzongkhag [24]. Phuentsholing, about $172 \mathrm{~km}$ away from Thimphu (Capital of Bhutan), is one of the commercial centers of Bhutan and is a developing border town with India. Due to the importance of trade and commerce, the town has to expand with upcoming infrastructures [8]. In this study, five sites were selected in Phuentsholing area: Kabreytar 1, Kabreytar 2, Pipaldhara 1, Pipaldhara 2 and Phuentsholing town as shown in Fig. 1. Elevation of the sites varies from $210 \mathrm{~m}$ (Phuentsholing town) to $392 \mathrm{~m}$ (Kabreytar 1), and it is mentioned in Table 1 and shown in Fig. 2.

The sites were chosen based on three factors, such as easy accessibility, terrain and vegetation cover. All the sites were accessible and near to the road available. The sites Pipaldhara 1, Pipaldhara 2 and Phuentsholing town were on plane grounds, whereas Kabreytar 1 and Kabreytar 2 were on sloping grounds with the angle of elevation with horizontal road surface of $37.38^{\circ}$ and $21.32^{\circ}$, respectively. Most of the sites have vegetation cover except Phuentsholing town.

The Phuentsholing area forms a part of the Himalayan foothill belt with a youthful topography steep topography and high precipitation. The Phuentsholing formation belongs to Baxa Group of Rocks consisting of quartzite, greenish gray, variegated and carbonaceous phyllite. The formation falls over the Main Boundary Thrust. The rocks in the area are crushed and weathered. The Himalaya being youngest mountain belt is still evolving due to northward movement of the Indian Plate toward the Eurasian plate. Hence, Himalaya is seismically active with large number of earthquakes. The region has weak intact rock strength having uniaxial compressive strength (UCS) value ranging from 0.60 to $1.50 \mathrm{MPa}$. There are also infrequent interbands of quartzite and dolomite that are strong rock with (UCS) values ranging from 34 to $55 \mathrm{MPa}$ [29].

\section{Field operation for SRT and MASW}

The equipment for SRT and MASW comprises source, detector and a seismograph. A sledgehammer of $8 \mathrm{~kg}$ was used to produce the seismic waves. Twelve geophones with a frequency of $4.5 \mathrm{~Hz}$ were used. Seismograph of DAQ LINK 3 was used to record the signals received from the geophones. An alignment was chosen along which the geophones were inserted firmly into the ground at regular intervals. The seismic cables were used to connect the geophones and the seismograph. The sledgehammer was hit on a metal plate to produce the seismic waves (P-wave). These waves travel into the ground through refraction and reflection. Only the critically refracted waves are recorded by the seismograph. The sledgehammer was hit three times on the metal plates at regular intervals of the geophones and at the mid of two geophones. Taking a stack of three, the number of stacks collected for the sites Kabreytar 1, Kabreytar 2, Pipaldhara 1, Pipaldhara 2 and Phuentsholing town was $68,27,28,33$, and 30 , respectively. Due to limited open plain area, the geophone interval for Kabreytar 1 was kept as $2 \mathrm{~m}$ and for the rest of the sites, it was $2.5 \mathrm{~m}$. The lengths of the profiles obtained including the offset distances were $37 \mathrm{~m}, 44.5 \mathrm{~m}, 53.5 \mathrm{~m}$ $81.5 \mathrm{~m}$, and $43.5 \mathrm{~m}$ for Kabreytar 1, Kabreytar 2, Pipaldhara 1, Pipaldhara 2, and Phuentsholing town, respectively.

\section{Data analysis}

\subsection{Analysis of primary waves}

A set of refracted P-arrival data are illustrated in Fig. 3. The SRT data were analyzed using the software 

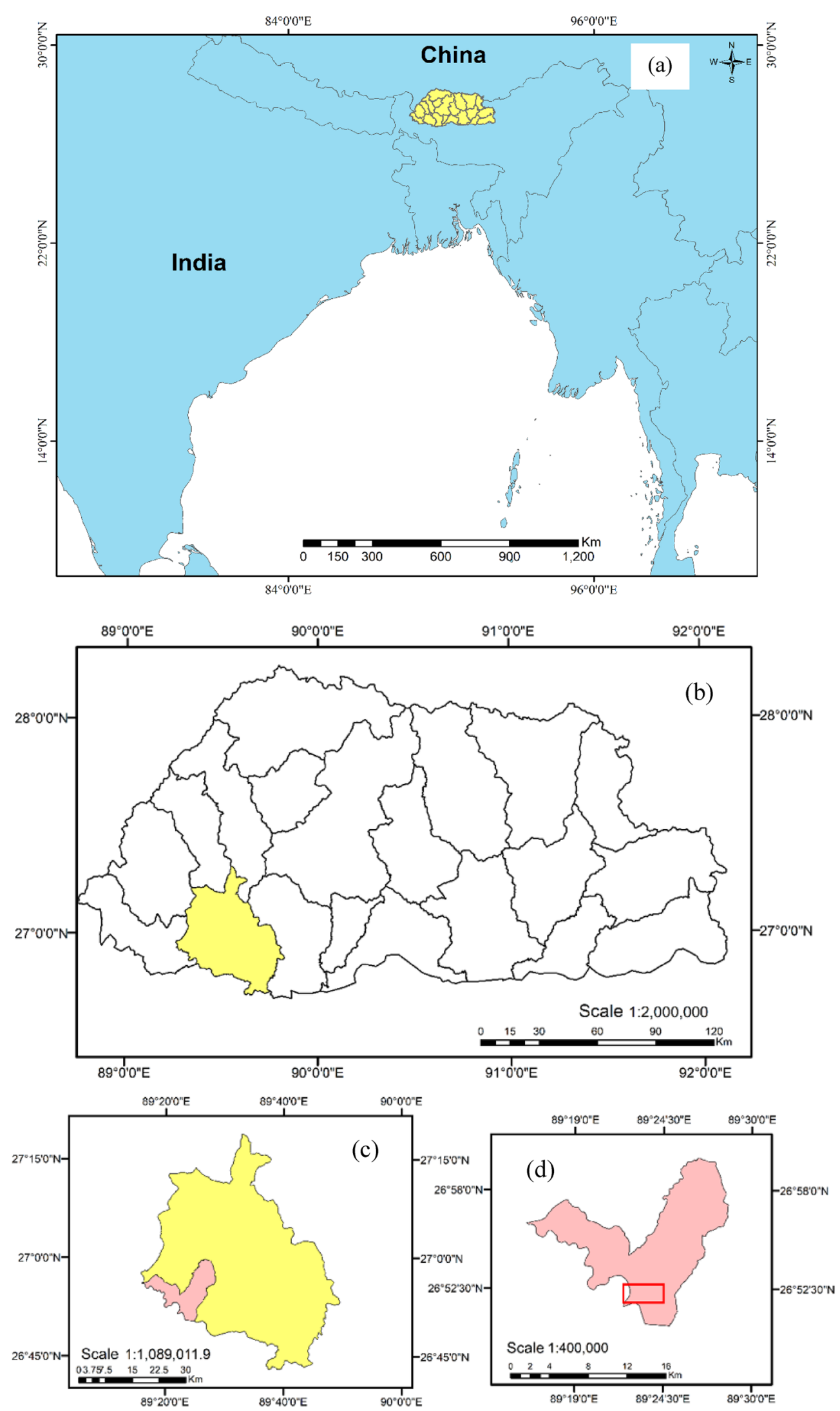

Fig. 1 Map showing a Bhutan on South East Asia Map, b Bhutan, c Chukha Dzongkhag, d Phuentsholing marking with study locations 
Table 1 Study area with coordinates and elevation

\begin{tabular}{|c|c|c|c|}
\hline Site No. & Site name & Site coordinates & Elevation (m) \\
\hline 1 & Kabreytar 1 & N $26^{\circ} 52^{\prime} 07.9^{\prime \prime}$, E $89^{\circ} 23^{\prime} 34.60^{\prime \prime}$ & $375-392$ \\
\hline 2 & Kabreytar 2 & N 265' $03.60^{\prime \prime}$, E $89^{\circ} 23^{\prime} 35.40^{\prime \prime}$ & $306-316$ \\
\hline 3 & Pipaldhara 1 & N 265' $58.30^{\prime \prime}$, E $89^{\circ} 22^{\prime} 55.40^{\prime \prime}$ & $234-236$ \\
\hline 4 & Pipaldhara 2 & N 265' $52^{\prime} 15.70^{\prime \prime}$, E $89^{\circ} 23^{\prime} 10.10^{\prime \prime}$ & $360-362$ \\
\hline 5 & Phuentsholing town & N $26^{\circ} 52^{\prime} 0.50^{\prime \prime}$, E $89^{\circ} 22^{\prime} 40.10^{\prime \prime}$ & 210 \\
\hline
\end{tabular}

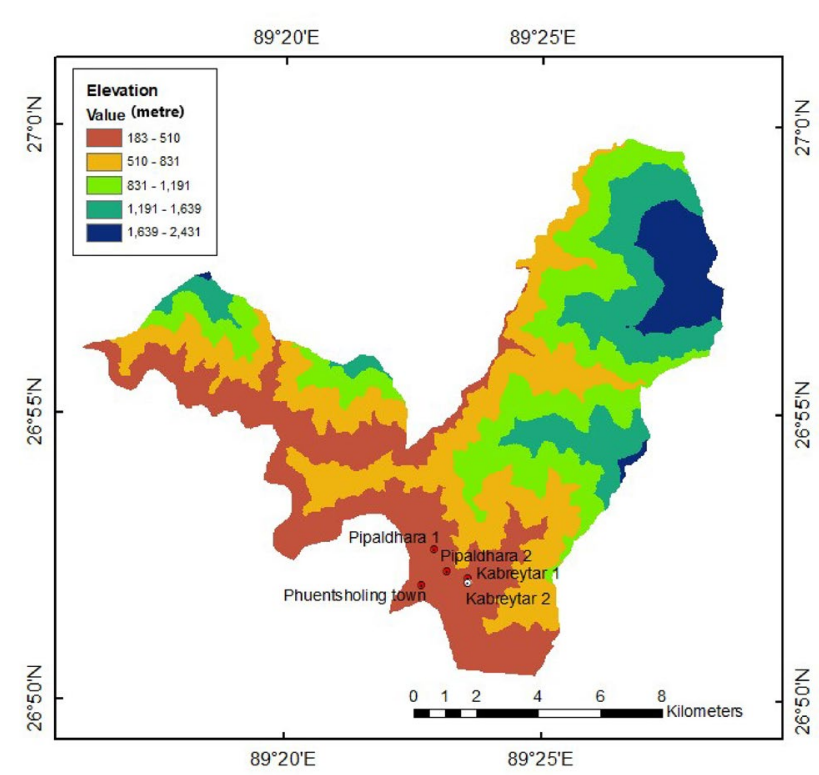

Fig. 2 Elevation map of study region

Seislmager/2D. The waveform are displayed as a graph between time and distance. The first arrival time of
P-wave was picked to generate the time-distance curve. The time-distance curve provides an initial velocity model (Fig. 4). The initial model is used for inversion; iteratively, the model is reduced with minimum root mean square (RMS) error for the observed and calculated travel times. Finally, the depth velocity model is presented in 2D (Fig. 5).

\subsection{Analysis of secondary waves (MASW analysis)}

For the analysis of shear waves, all the waveforms generated for a site have to be opened at once using Pick win, SeisImager/SW. Similar to the primary waves, the shot points and geophone interval should be edited for all the files opened. Next, the common midpoint (CMP) crossrelation gathers have to be generated (Fig. 6). CMP shows the receiver locations the shot point locations. The yellow dots are the receiver locations, i.e., the position of the geophones and the blue dots are the locations at which the hammer was hit. The next step includes the generation of the dispersion curve using the WaveEq module. The dispersion curve is shown as a graph between phase velocity and the frequency. From the dispersion curve generated, 1D shear wave velocity profile (Fig. 7) was generated. The

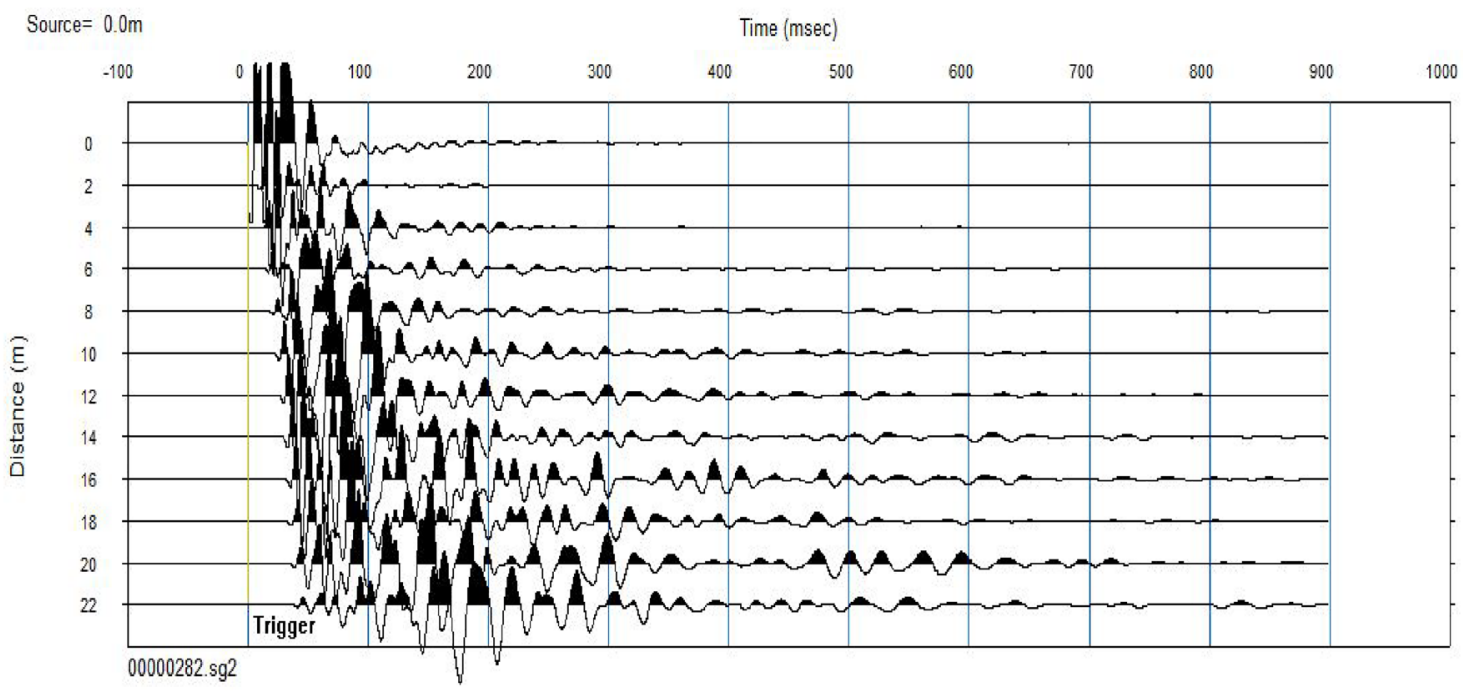

Fig. 3 Sample of raw data collected from Kabreytar 1 
Fig. 4 Travel time graph for Kabreytar 1

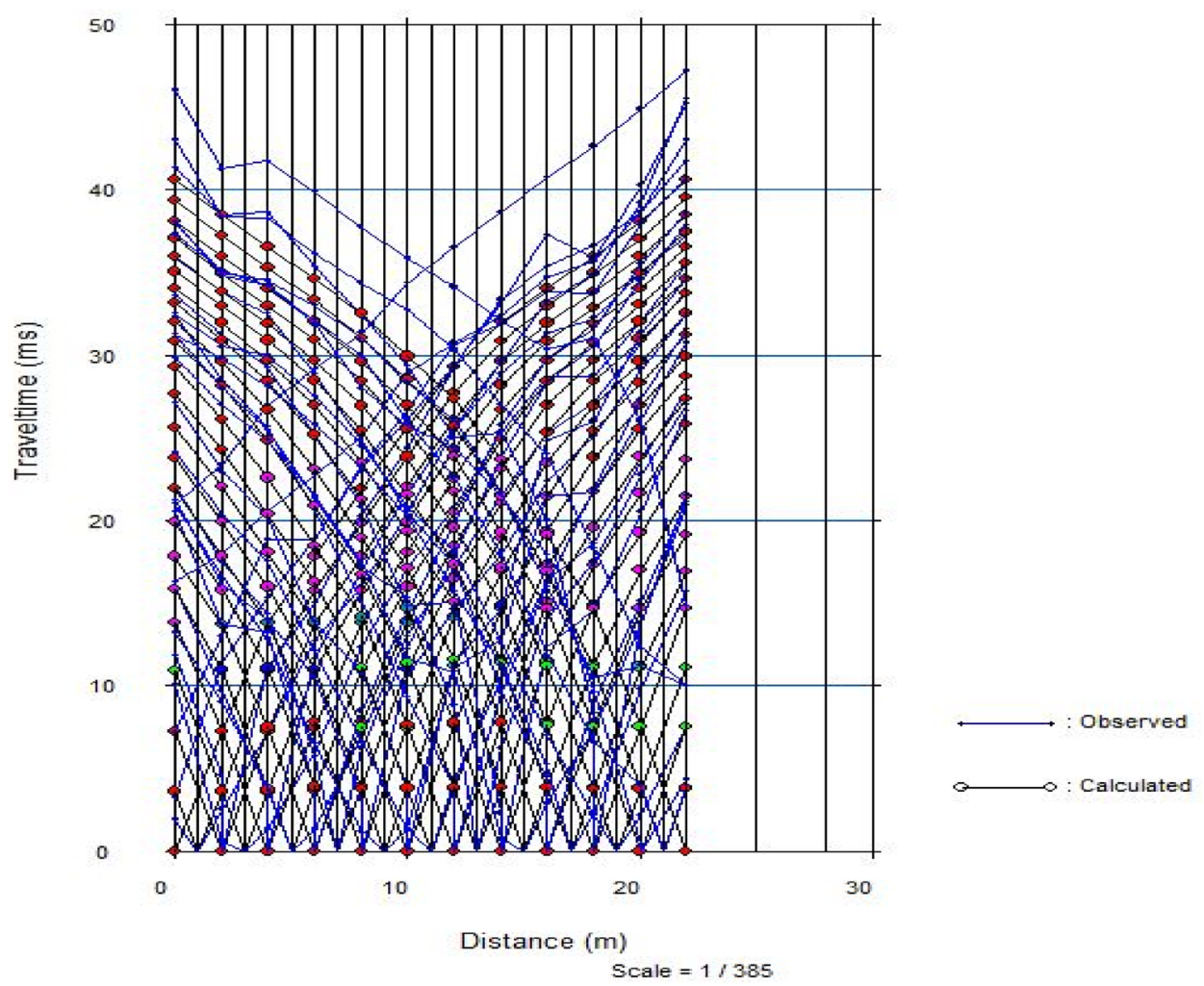

1D shear wave velocity profile is shown as a plot between depth and velocity. The final step is to perform inversion analysis to get the 2D shear wave velocity, which is obtained using Geoplot (Fig. 8).

\section{Results and discussion}

Since no prior soil tests were done in the past and no information on the soil types was available for the sites, the velocity data were interpreted referring to Appendix B; Clause 3.2 of the IS: 1892-1979 [13]. Soil parameters such as density $(\rho)$, Poisson's ratio $(\sigma)$, Young's modulus $(E)$, Shear modulus $(\mu), N$-value and ultimate bearing capacity $\left(q_{\mathrm{ult}}\right)$ were calculated using equations as shown in Table 2. From the velocity of primary waves $\left(V_{p}\right)$, the types of soil found in these sites are sand, sandy clay, gravels and shales which are presented in Table 3. Table 4 shows the soil parameters of the study areas. The density value for all the sites ranges from 13.0 to 16.5 $\mathrm{kN} / \mathrm{m}^{3}$ up to the depth of $5 \mathrm{~m}$ with minimum at location Pipaldhara 1 and maximum in the location Phuentsholing town and then increases up to $19.3 \mathrm{kN} / \mathrm{m}^{3}$ at depth of $10 \mathrm{~m}$ for location Kabreytar 2. The value of Young's modulus and shear modulus ranges from 240-590 MPa to $85-215 \mathrm{MPa}$ up to the depth of $5 \mathrm{~m}$ with the least at Kabreytar 1 and the highest at Phuentsholing town, respectively. The maximum value of Young's modulus and shear modulus is $733.3 \mathrm{MPa}$ and $260.78 \mathrm{MPa}$ at a depth of $10 \mathrm{~m}$ observed in Phuentsholing town location. From the same table, it is seen that the density, Young's modulus, shear modulus, $\mathrm{N}$-value increase with depth which indicates that the soil becomes stiffer as the depth of soil layer increases. The stiffer soil is always hold good for construction since bearing capacity of soil increases with stiffness. The bearing capacity estimate indicates that the safe depth for the foundation has to be more than two meters. At the Kabreytar site 2, the results show existence of water in the soil at a depth of $10 \mathrm{~m}$. This site needs careful treatment to avoid soil liquefaction. As proposed by NEHRP [3], the site classification should be established as per mean shear wave velocity for topmost $30 \mathrm{~m}\left(V_{s, 30}\right)$ using Eq. (1).

$V_{\mathrm{s}, 30}=\frac{30}{\sum_{i=1, N} \frac{h_{i}}{V_{\mathrm{s}, i}}}(\mathrm{~m} / \mathrm{s})$

Here, $h_{i}, V_{s, i}$ are the thickness and shear wave velocity of the $i$ th layer of $N$ soil layer in total of existing top $30 \mathrm{~m}$, respectively. In the present study, for all the five sites considered, the average shear wave velocity for top $30 \mathrm{~m}$ $\left(V_{s, 30}\right)$ lies between 180 and $360 \mathrm{~m} / \mathrm{s}$. Hence, based on 


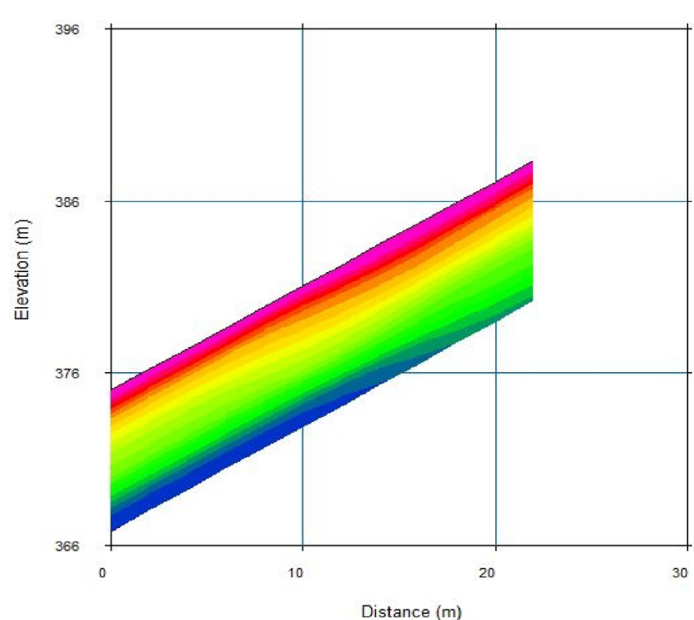

(a)

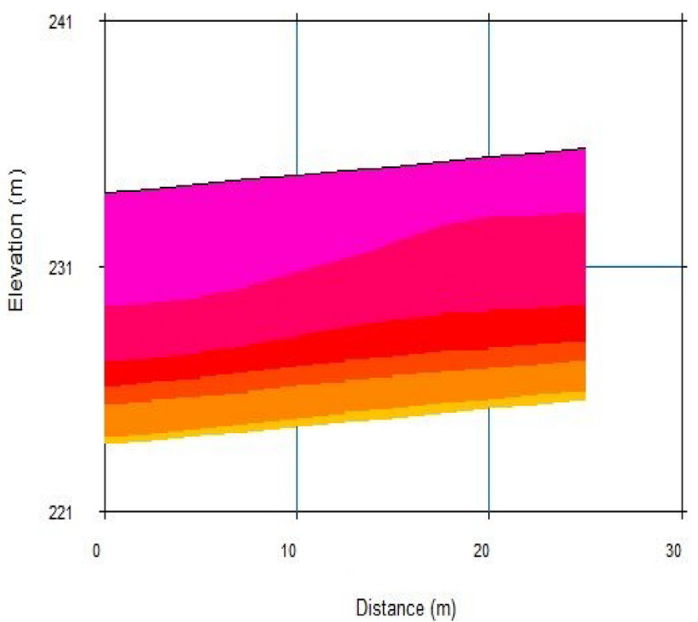

(c)

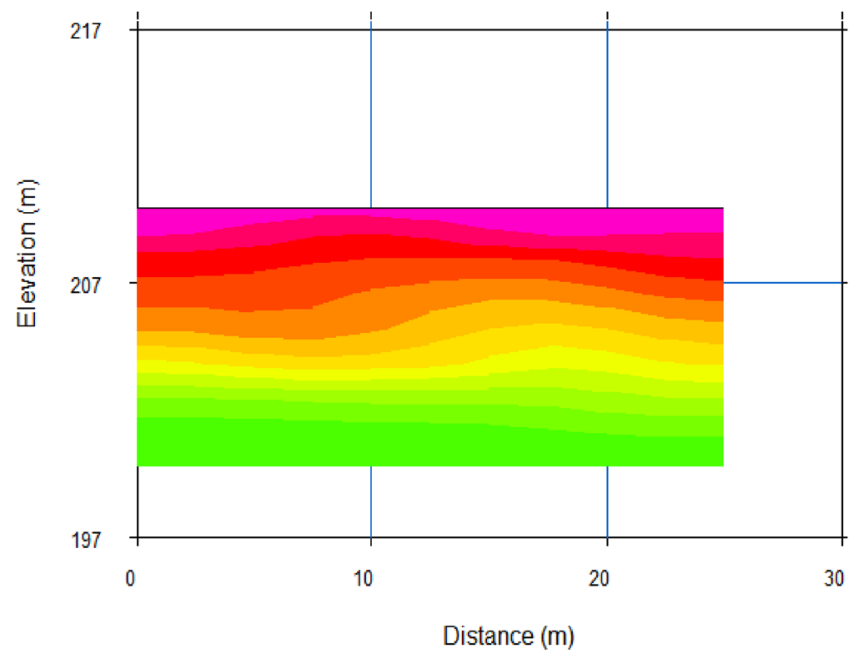



(b)

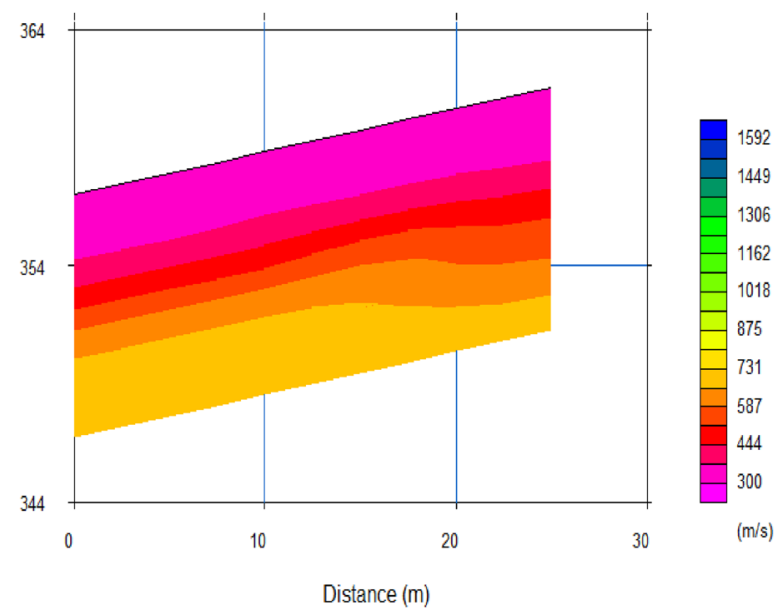

(d)

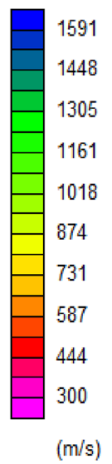

(e)

Fig. 5 Two-dimensional depth and P-wave velocity profile of a Kabreytar 1, b Kabreytar 2, c Pipaldhara 1, d Pipaldhara 2, e Phuentsholing town

\section{SN Applied Sciences}


Fig. 6 CMP cross-relation gathers from Kabreytar 1

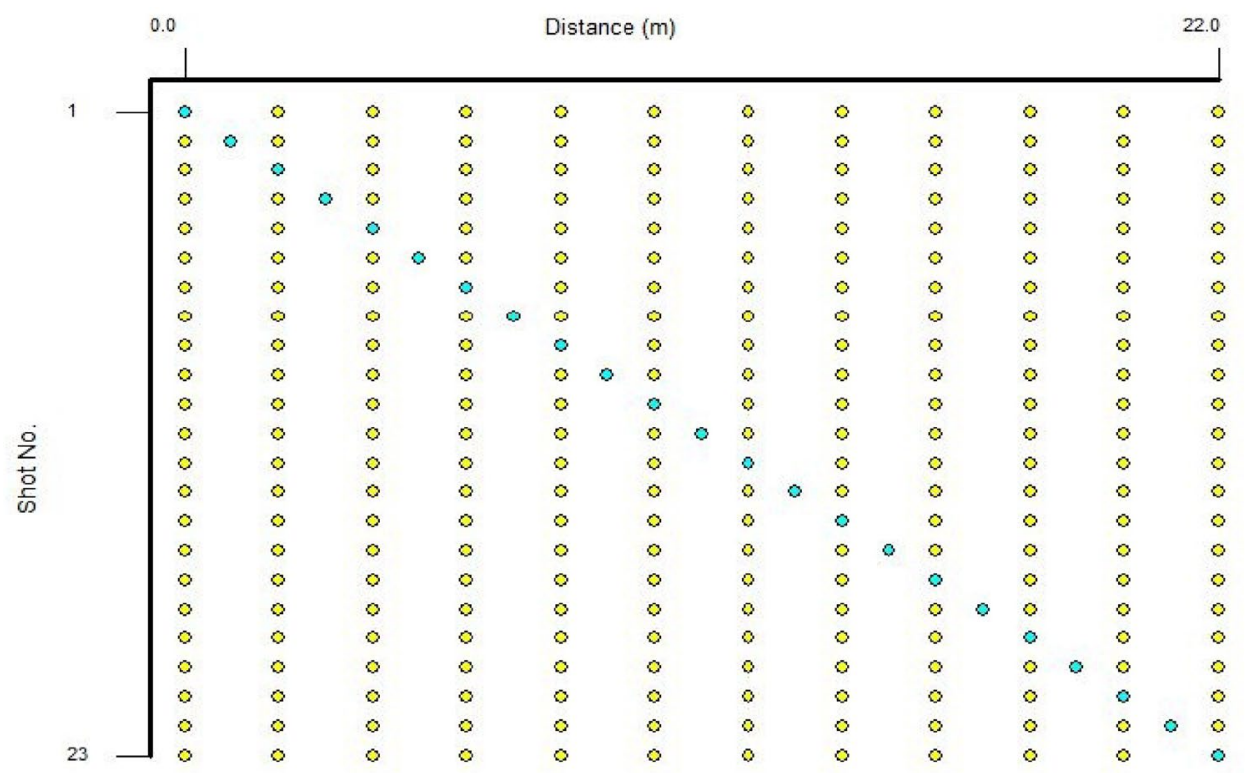

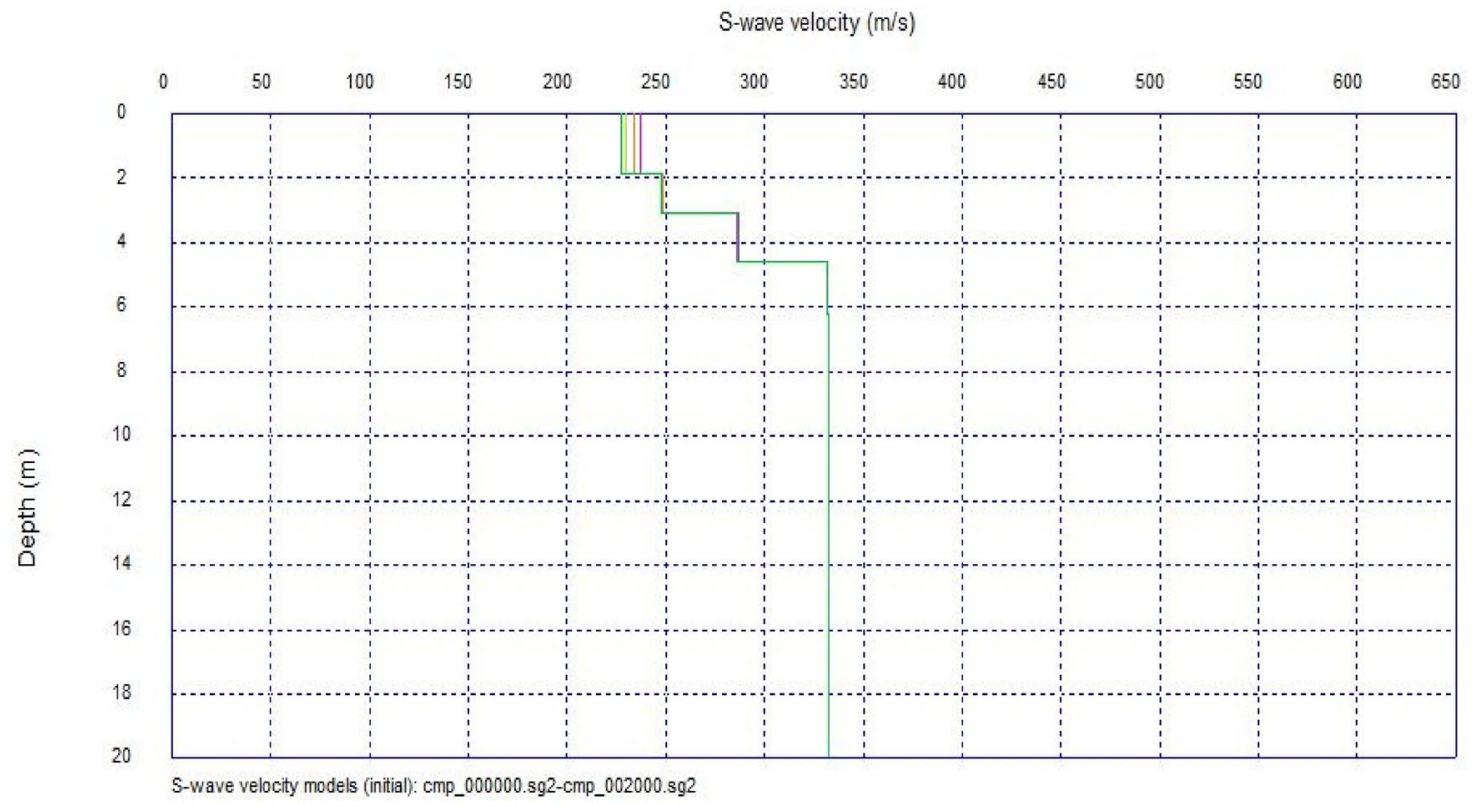

Fig. 7 One-dimensional shear wave velocity profile from Kabreytar 1

NEHRP site classification [3], all the sites can be grouped as Site Class D.

\section{Ground response analysis}

The results of the geophysical method indicate that all the five sites belong to site class ' $\mathrm{D}$ ' $\left(180 \leq V_{s} \leq 360\right)$ as per NEHRP soil classification. In general, sand, silt and stiff clays with SPT value of $15 \leq N \leq 50$ and shear strength of $50 \mathrm{kPa} \leq S \leq 100 \mathrm{kPa}$ belong to Site Class D.
The amplification factors proposed by previous researchers $[22,27]$ can be directly used to assess the ground surface spectral acceleration if the input motion at bedrock is known. However, equivalent ground response analysis based on the subsurface profile at the site will give a more reliable estimate of site amplification value for the surface level and the variation of acceleration with varying depth. DEEPSOIL v7 [9] was used to perform equivalent ground response analysis using the shear wave velocity profiles and soil properties estimated from the geophysical methods. Figure 9 presents the typical subsurface soil profile 
Fig. 8 Two-dimensional depth and S-wave velocity profiles, a Kabreytar 1, b Kabreytar 2, c Pipaldhara 1, d Pipaldhara 2, e Phuentsholing town

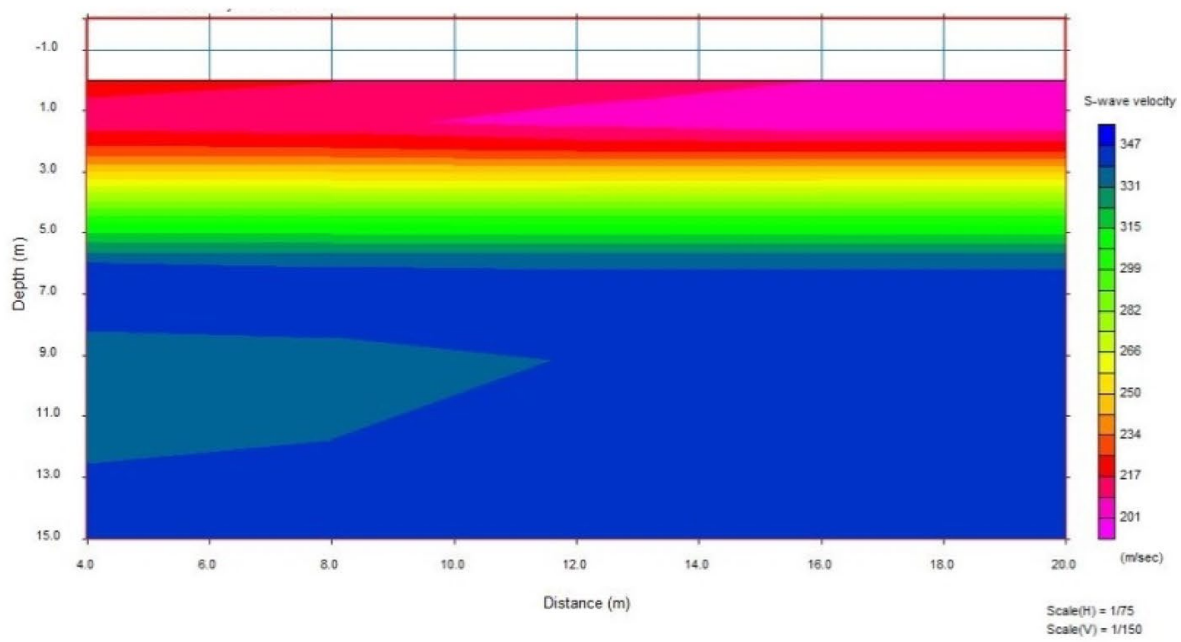

(a)

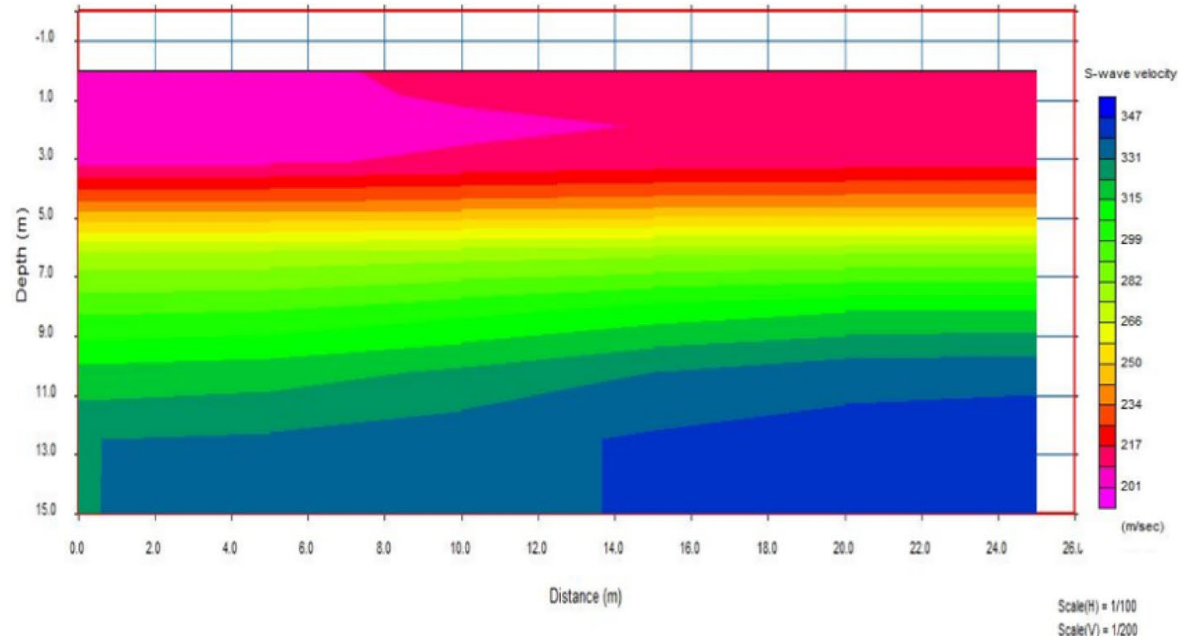

(b)



(c) 
Fig. 8 (continued)



(d)

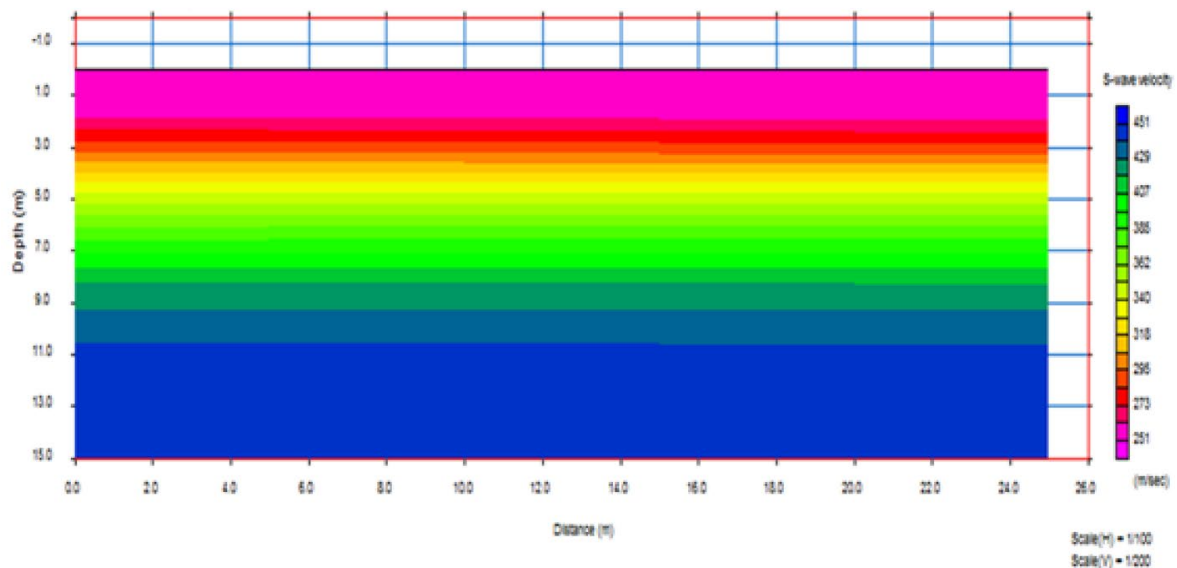

(e)

Table 2 List of equations used to determine soil parameters in the present study

\begin{tabular}{llll}
\hline SI. No. & Soil parameters & Equations used & Reference \\
\hline 1 & Density & $\rho=0.31 V_{\mathrm{p}}^{0.25}$ & Keceli [15] \\
2 & Poisson's ratio & $\sigma=\frac{1}{2}\left(1-\frac{1}{\left(V_{\mathrm{p}}^{2} / V_{\mathrm{s}}^{2}\right)-1}\right)$ & Ahmed Al-Heety and Al-Saigh [1] \\
3 & Young's modulus & $E=\left(\rho V_{\mathrm{s}}^{2}\right)\left(\frac{3 V_{\mathrm{p}}^{2}-4 V_{\mathrm{s}}^{2}}{V_{\mathrm{p}}^{2}-V_{\mathrm{s}}^{2}}\right)$ & Keceli [15] \\
4 & Shear modulus & $\mu=\frac{E}{2(1+\sigma)}$ & Ahmed Al-Heety and Al-Saigh [1] \\
5 & N-value & $N=\left(\frac{V_{\mathrm{s}}}{76.55}\right)$ & Khalil and Hanafy [16] \\
6 & Ultimate bearing capacity & $q_{\mathrm{ult}}=\frac{V_{\mathrm{s}}^{2.4}}{1590}$ & Imai and Yoshimura [12] \\
\hline
\end{tabular}

The analysis in DEEPSOIL considers each and every layer of the soil profile, and within a layer, the properties like $V_{s^{\prime} 30}$ were varied for the site. It was seen that the acceleration value gets amplified as the waves travel to the top of the surface. The plot showing the variation of peak of the site Kabreytar 1 . The ground response analysis was carried out for the site considering a scenario earthquake with input motion from the Chi-Chi earthquake. The acceleration time history for the input motion of Chi-Chi earthquake is shown in Fig. 10. 
Table 3 Velocity ranges and soil types at the sites

\begin{tabular}{|c|c|c|c|c|}
\hline SI. No. & Site & $V_{\mathrm{p}}(\mathrm{m} / \mathrm{s})$ & $V_{\mathrm{s}}(\mathrm{m} / \mathrm{s})$ & Soil type (IS 1892:1979) \\
\hline 1 & Kabreytar 1 & $300-1175$ & $214-348$ & $\begin{array}{l}\text { Up to } 1 \mathrm{~m} \text { sand and top soil } \\
1-5 \mathrm{~m} \text { sandy clay } \\
5-8 \mathrm{~m} \text { gravels } \\
8-10 \mathrm{~m} \text { shale }\end{array}$ \\
\hline 2 & Kabreytar 2 & $300-1596$ & $260-538$ & $\begin{array}{l}\text { Up to } 2 \mathrm{~m} \text { sand and top soil } \\
2-4.5 \mathrm{~m} \text { sandy clay } \\
4.5-6 \mathrm{~m} \text { gravel with shale } \\
6-10 \mathrm{~m} \text { shale and water in loose soil }\end{array}$ \\
\hline 3 & Pipaldhara 1 & $300-659$ & $185-385$ & $\begin{array}{l}\text { Up to } 5 \mathrm{~m} \text { mixture sand, top soil and sandy clay } \\
5-10 \mathrm{~m} \text { sandy clay }\end{array}$ \\
\hline 4 & Pipaldhara 2 & $300-733$ & $235-323$ & $\begin{array}{l}\text { Up to } 2 \mathrm{~m} \text { sand and top soil } \\
2-6 \mathrm{~m} \text { sandy clay } \\
6-10 \mathrm{~m} \text { gravels }\end{array}$ \\
\hline 5 & Phuentsholing town & $300-1305$ & $251-409$ & $\begin{array}{l}\text { Up to } 1 \mathrm{~m} \text { sand and top soil } \\
1-4 \mathrm{~m} \text { sandy clay } \\
4-5 \mathrm{~m} \text { gravels } \\
5-10 \mathrm{~m} \text { shale }\end{array}$ \\
\hline
\end{tabular}

Table 4 Soil parameters of the study areas

\begin{tabular}{|c|c|c|c|c|c|c|c|c|c|}
\hline SI. No. & Site & Layer & Depth (m) & Density $\left(\mathrm{kN} / \mathrm{m}^{3}\right)$ & Poisson's ratio & $\begin{array}{l}\text { Young's } \\
\text { modulus } \\
\left(\mathrm{kN} / \mathrm{m}^{2}\right)\end{array}$ & $\begin{array}{l}\text { Shear } \\
\text { modulus } \\
\left(\mathrm{kN} / \mathrm{m}^{2}\right)\end{array}$ & $N$-value & $\begin{array}{l}\text { Ultimate bearing } \\
\text { capacity }\left(\mathrm{kN} / \mathrm{m}^{2}\right)\end{array}$ \\
\hline \multirow[t]{4}{*}{1} & \multirow[t]{4}{*}{ Kabreytar 1} & 1 & Up to 1 & 14.2 & 0.33 & 184.64 & 69.34 & 11 & 266.16 \\
\hline & & 2 & $1-5$ & 16.0 & 0.42 & 244.48 & 86.29 & 13 & 311.60 \\
\hline & & 3 & $5-8$ & 17.4 & 0.44 & 411.41 & 156.48 & 22 & 570.47 \\
\hline & & 4 & $8-10$ & 18.0 & 0.45 & 486.47 & 217.62 & 30 & 791.39 \\
\hline \multirow[t]{4}{*}{2} & \multirow[t]{4}{*}{ Kabreytar 2} & 1 & Up to 2 & 15.3 & 0.42 & 204.31 & 71.88 & 10 & 254.75 \\
\hline & & 2 & $2-4.5$ & 16.1 & 0.44 & 254.83 & 88.29 & 12 & 305.30 \\
\hline & & 3 & $4.5-6$ & 18.1 & 0.47 & 423.01 & 144.00 & 19 & 477.75 \\
\hline & & 4 & $6-10$ & 19.3 & 0.48 & 579.72 & 196.39 & 25 & 643.77 \\
\hline \multirow[t]{2}{*}{3} & \multirow[t]{2}{*}{ Pipaldhara 1} & 1 & Up to 6 & 12.9 & 0.17 & 258.72 & 110.80 & 18 & 470.45 \\
\hline & & 2 & $6-10$ & 15.5 & 0.22 & 567.24 & 233.03 & 38 & 1011.03 \\
\hline \multirow[t]{3}{*}{4} & \multirow[t]{3}{*}{ Pipaldhara 2} & 1 & Up to 2 & 13.7 & 0.17 & 184.20 & 78.84 & 13 & 324.42 \\
\hline & & 2 & $2-6$ & 14.6 & 0.29 & 277.32 & 108.47 & 17 & 440.76 \\
\hline & & 3 & $6-10$ & 15.9 & 0.37 & 445.76 & 163.47 & 25 & 649.58 \\
\hline \multirow[t]{4}{*}{5} & \multirow[t]{4}{*}{ Phuentsholing town } & 1 & Up to 1 & 15.9 & 0.43 & 286.55 & 100.46 & 14 & 361.26 \\
\hline & & 2 & $1-4$ & 14.8 & 0.19 & 355.99 & 149.34 & 25 & 637.42 \\
\hline & & 3 & $4-5$ & 16.5 & 0.38 & 582.72 & 211.63 & 32 & 847.08 \\
\hline & & 4 & $5-10$ & 17.3 & 0.41 & 733.29 & 260.78 & 38 & 1026.74 \\
\hline
\end{tabular}

ground acceleration (PGA) with varying depth is shown in Fig. 11a for the site Kabreytar 1. The amplification factor was estimated as 1.36 by taking the ratio of surface PGA to the PGA at the bottom layer. The ground response analysis considering the varying soil profile gives a more accurate and reliable estimate of the amplification factor. The response spectrum showing spectral acceleration corresponding to various natural periods (of the structure) at the site Kabreytar 1 for an input motion from a scenario earthquake of Chi-Chi earthquake is shown in Fig. $11 \mathrm{~b}$. Similar analyses were carried out for other sites as well, and the results are presented from Figs. 12, 13, 14 and 15. The surface level PGA values and estimated amplification factors for the considered sites in Bhutan Himalaya for input motion of Chi-Chi earthquake at the bottom layer are presented in Table 5. It was observed that amplification 

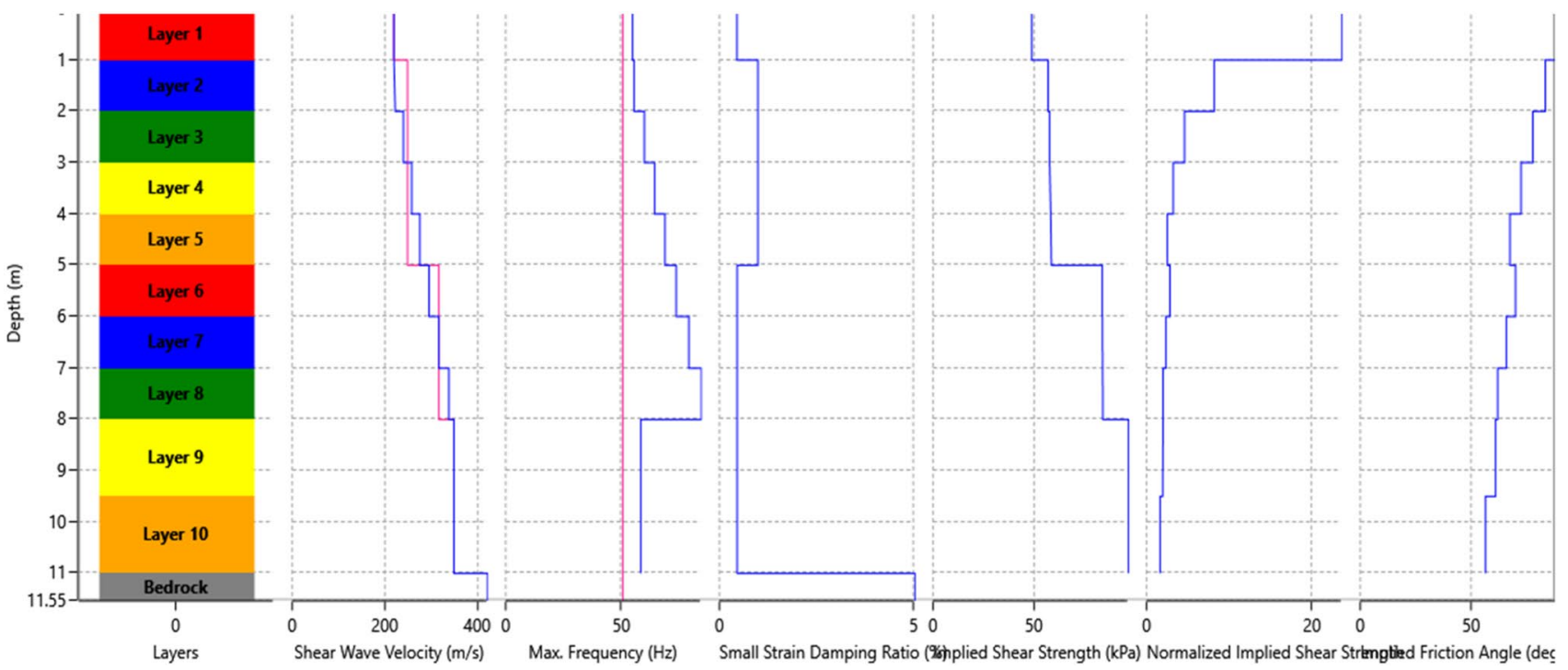

Fig. 9 Soil profile of Kabreytar 1 with respect to depth

factor is high for Kabreytar 1 and negligible for the site Phuentsholing town.

\section{Conclusion}

This paper presented near-surface seismic refraction tomography and MASW studies for site characterization in Phuentsholing, Bhutan Himalaya. Although various physical methods such as borehole testing, standard penetration test and drilling are available for determining soil parameters, these are not always easy to execute. Seismic refraction tomography (SRT) is an alternative. In this study, five sites were selected in Phuentsholing for the SRT and

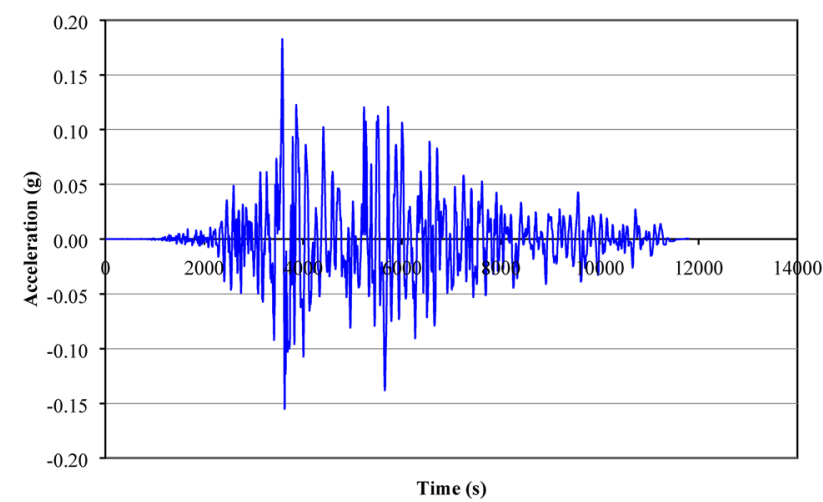

Fig. 10 Acceleration time history for the input motion of Chi-Chi earthquake at bottom layer
MASW studies. The major findings and conclusions are summarized below.

1. From the velocity profiles, the soil found was sand, sandy clay and shale. No hard rock strata were found down to the depth of $10 \mathrm{~m}$.

2. The density value for all the sites ranges from 13.0 to $16.5 \mathrm{kN} / \mathrm{m}^{3}$ up to the depth of $5 \mathrm{~m}$ with minimum at location Pipaldhara 1 and maximum in the location Phuentsholing town and then increases up to 19.3 $\mathrm{kN} / \mathrm{m}^{3}$ at depth of $10 \mathrm{~m}$ for location Kabreytar 2 .

3. Presence of ground water in the soil at depth of $10 \mathrm{~m}$ at the site Kabreytar 2 may cause soil liquefaction; the ultimate bearing capacity is comparatively low with compared to other locations at a depth of $10 \mathrm{~m}$.

4. The value of Young's modulus and shear modulus ranges from 240-590 MPa to 85-215 MPa up to the depth of $5 \mathrm{~m}$ with the least at Kabreytar 1 and the highest at Phuentsholing town, respectively.

5. The maximum value of Young's modulus and shear modulus is $733.3 \mathrm{MPa}$ and $260.78 \mathrm{MPa}$ at a depth of $10 \mathrm{~m}$ observed in Phuentsholing town location.

6. Bearing capacity estimates show feasibility for engineering construction. At the site Kabreytar 1 , at the competent layer, the safe depth for construction is at $5 \mathrm{~m}$.

7. At sites Pipaldhara 1 and Phuentsholing town, at second layer and fourth layer, respectively, the ultimate bearing capacity reaching up to $1000 \mathrm{kN} / \mathrm{m}^{2}$.

8. The SRT requires lesser time for field work and data analysis than any other geophysical experiments. 
Fig. 11 a Variation of PGA value with varying depth for site Kabreytar 1 , b response spectra at the bottom layer and top layer for $\mathrm{Chi}-\mathrm{Chi}$ earthquake input motion at site Kabreytar 1

\section{PGA (g)}

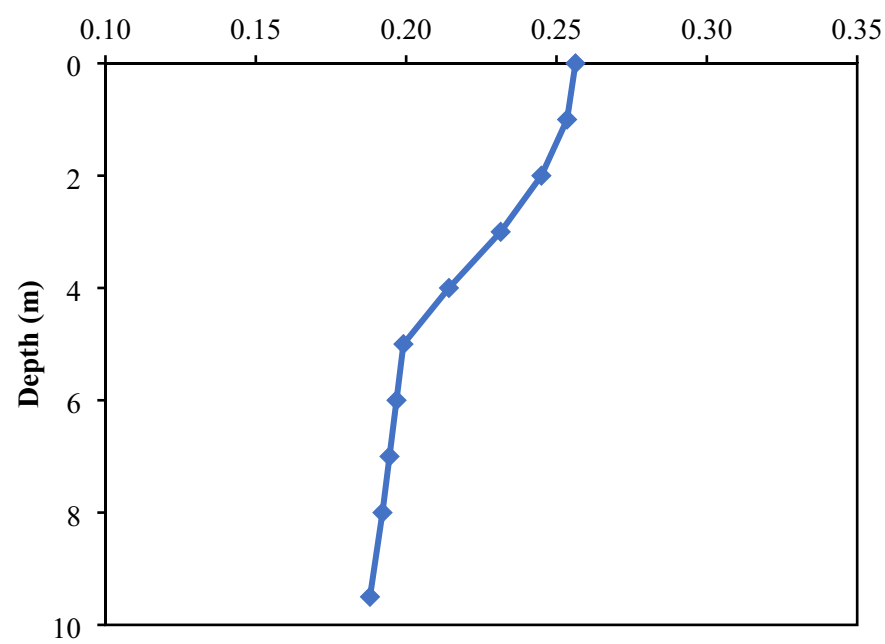

(a)

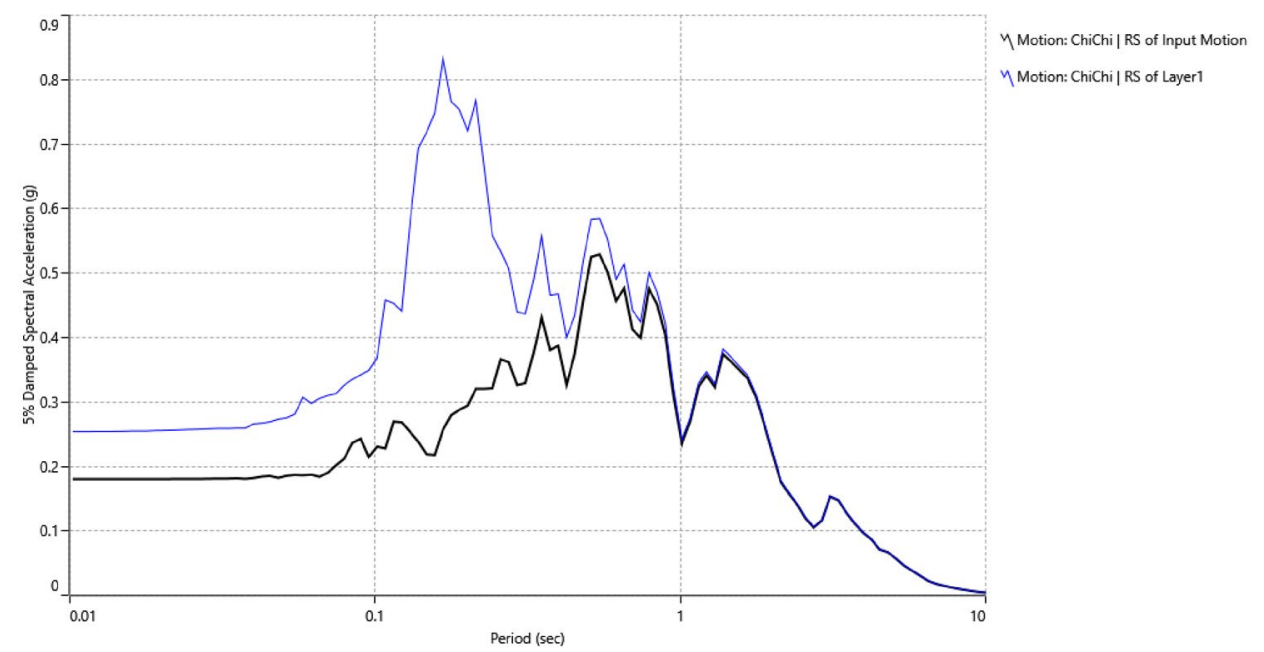

(b) 
Fig. 12 a Variation of PGA value with varying depth for site Kabreytar 2, b response spectra at the bottom layer and top layer for $\mathrm{Chi}-\mathrm{Chi}$ earthquake input motion at site Kabreytar 2
PGA (g)



(a)



(b) 
Fig. 13 a Variation of PGA value with varying depth for site Pipaldhara $1, \mathbf{b}$ response spectra at the bottom layer and top layer for $\mathrm{Chi}-\mathrm{Chi}$ earthquake input motion at site Pipaldhara 1
PGA (g)

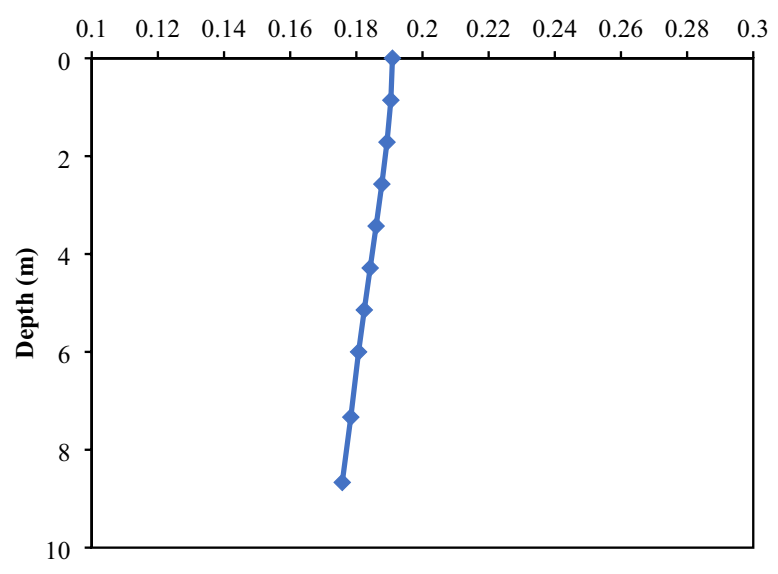

(a)



(b) 
Fig. 14 a Variation of PGA value with varying depth for site Pipaldhara 2, b response spectra at the bottom layer and top layer for $\mathrm{Chi}-\mathrm{Chi}$ earthquake input motion at site Pipaldhara 2

\section{PGA (g)}



(a)

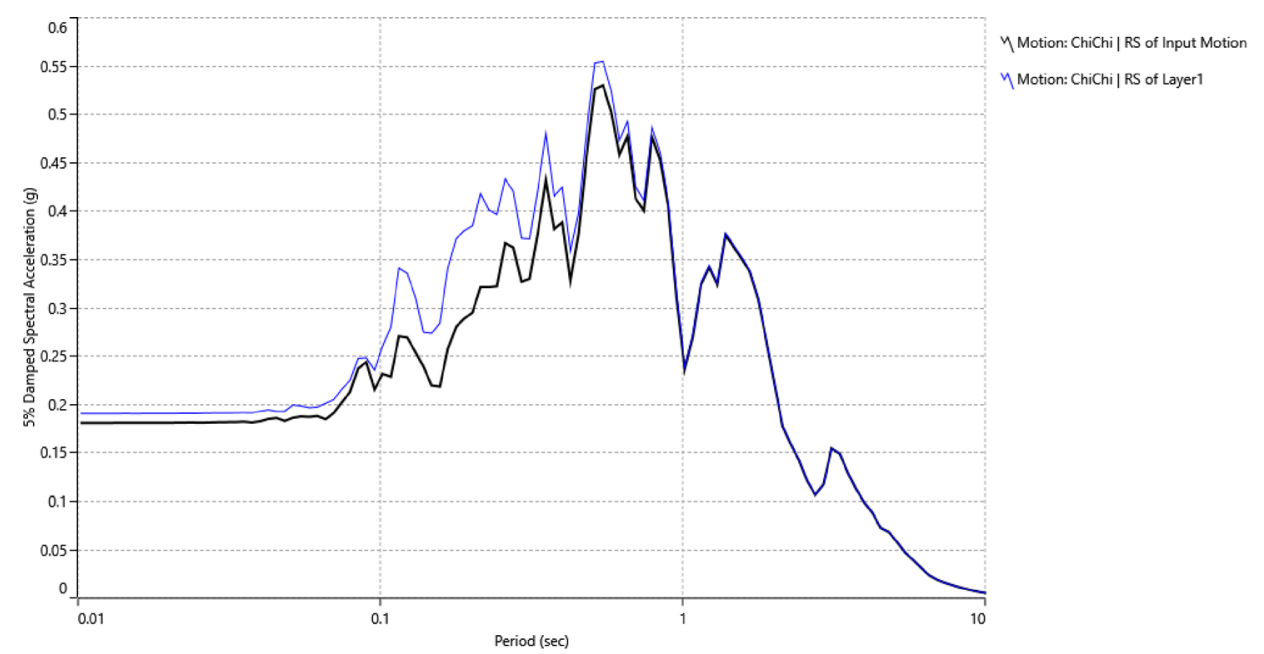

(b) 
Fig. 15 a Variation of PGA value with varying depth for site Phuentsholing town, $\mathbf{b}$ response spectra at the bottom layer and top layer for Chi-Chi earthquake input motion at site Phuentsholing town
PGA (g)

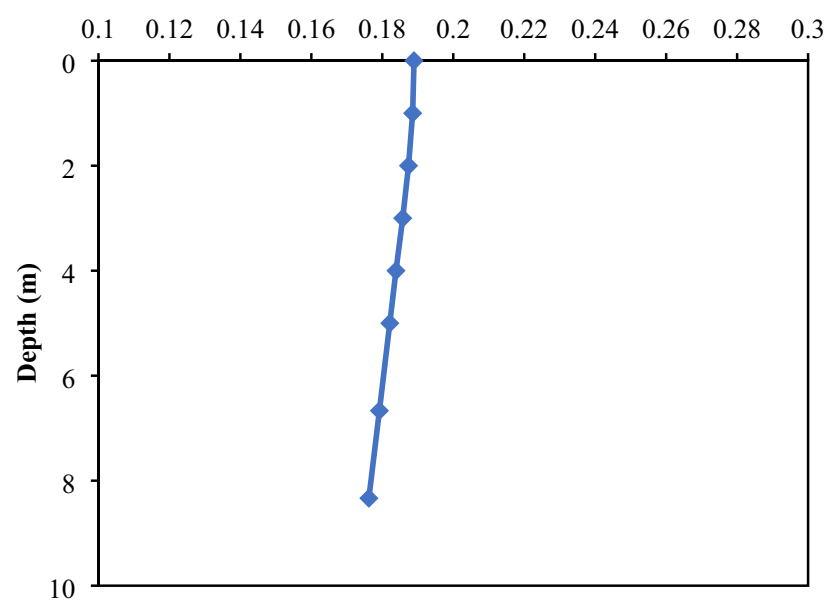

(a)

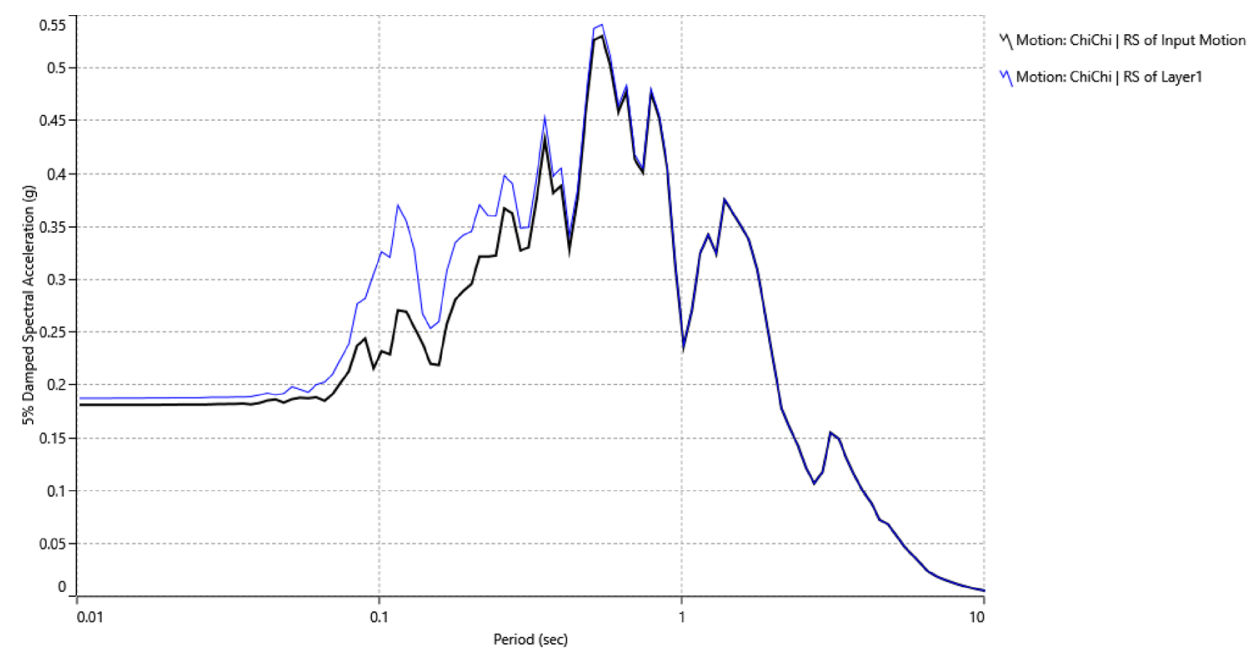

(b)
Table 5 Surface PGA values and amplification factors for different sites in Bhutan Himalaya considering Chi-Chi earthquake input motion

\begin{tabular}{lll}
\hline Site & Surface PGA (g) & $\begin{array}{l}\text { Amplifica- } \\
\text { tion factor }\end{array}$ \\
\hline Kabreytar 1 & 0.256 & 1.36 \\
Kabreytar 2 & 0.194 & 1.14 \\
Pipaldhara 1 & 0.191 & 1.08 \\
Pipaldhara 2 & 0.192 & 1.11 \\
Phuentsholing town & 0.189 & 1.07 \\
\hline
\end{tabular}

9. Based on the weighted average shear wave velocity for top $30 \mathrm{~m}$, the identified five sites were classified as site class $D$ as per NEHRP site classification

10. Site-specific ground response analyses were performed for all the five sites based on shear wave velocity profiles and soil parameters at different depths. The amplification factors estimated for the sites Kabreytar 1, Kabreytar 2, Pipaldhara 1, Pipaldhara 2 and Phuentsholing town were 1.36, 1.14, 1.08, 1.11 and 1.07 , respectively. 
Author's contribution RS contributed to the methodology, formal analysis, investigation, visualization, validation and writing of the manuscript; SK contributed to the methodology, formal analysis, DD contributed to project administration, funding support and visualization; KC, SR, STT and KY contributed to the data acquisition and data curation and contributed to the editing of the manuscript.

Funding This research is supported by Department of Geology and Mines, Ministry of Economic Affairs, Royal Govt. of Bhutan, by providing the instruments and College of Science and Technology, Royal University of Bhutan, by providing the local logistics.

\section{Compliance with ethical standards}

Conflict of interest The authors declare that they have no known competing financial interests or personal relationships that could have appeared to influence the work reported in this paper.

Open Access This article is licensed under a Creative Commons Attribution 4.0 International License, which permits use, sharing, adaptation, distribution and reproduction in any medium or format, as long as you give appropriate credit to the original author(s) and the source, provide a link to the Creative Commons licence, and indicate if changes were made. The images or other third party material in this article are included in the article's Creative Commons licence, unless indicated otherwise in a credit line to the material. If material is not included in the article's Creative Commons licence and your intended use is not permitted by statutory regulation or exceeds the permitted use, you will need to obtain permission directly from the copyright holder. To view a copy of this licence, visit http://creativecommons .org/licenses/by/4.0/.

\section{References}

1. Ahmed Al-Heety A, Al-Saigh N (2014) Seismic refraction tomography and MASW Survey for Geotechnical Evaluation of soil for the Teaching Hospital Project at Mosul University. J Zankoy Sulaimani Part A (JZS-A) 18(1):77-86

2. Azwin I, Saad R, Nordianac M (2013) Applying the seismic refraction tomography for site characterization. APCBEE Procedia 5:227-231. https://doi.org/10.1016/j.apcbee.2013.05.039

3. Building Seismic Safety Council (BSSC) (1997) NEHRP recommended provisions for seismic regulations for new buildings, part 1-provisions, 1997th edn. Building Seismic Safety Council, Washington, DC

4. Buddensick ML, Sheng J, Crosby T (2007) Colluvial wedge imaging using traveltime and waveform tomography along the Wasatch fault near Mapleton. Geophys J Int 172:686-697. https ://doi.org/10.1111/j.1365-246X.2007.03667.x

5. Cardarelli E, Cercato M, Cerreto A, Filippo GD (2009) Electrical resistivity and seismic refraction tomography to detect buried cavities. Geophys Prospect 58:1-11. https://doi.org/10.111 1/j.1365-2478.2009.00854.x

6. Chiemeke CC, Osazuwa IB (2014) Assessment of the response of seismic refraction tomography and resistivity imaging to the same geologic environment: a case study of Zaria basement complex in North Central Nigeria. Int Sch Sci Res Innov 8(10):719-722

7. Fkirin MA, Badawy S, El Deery MF (2016) Seismic refraction method to study subsoil structure. J Geol Geophys 5(5):1-6

8. Gariano SL, Sarkar R, Dikshit A, Dorji K, Brunetti MT, Peruccacci S, Melillo M (2019) Automatic calculation of rainfall thresholds for landslide occurrence in Chukha Dzongkhag, Bhutan. Bull Eng Geol Environ 78:4325-4332

9. Hashash YMA, Musgrove MI, Harmon JA, Groholski DR, Phillips CA, Park D (2016) DEEPSOIL 6.1, user manual. Board of Trustees of University of Illinois at Urbana-Champaign, Urbana

10. Hayashi K, Takahashi T (2001) High resolution seismic refraction method using surface and borehole data for site characterization of rocks. Int J Rock Mech Min Sci 38:807-813

11. Hiltunen DR, Cramer BJ (2008) Application of seismic refraction tomography in karst terrane. J Geotech Geo-Environ Eng 134:938-948. https://doi.org/10.1061/ (ASCE) 1090-0241(2008)134:7(938)

12. Imai T, Yoshimura M (1976) The relation of mechanical properties of soils to P and S-wave velocities for soil ground in Japan. Urana Research Institute, OYO Corporation, Tokyo

13. IS Code 1892 (1979) Code of practice for subsurface investigation for foundations. Bureau of Indian Standards, Geneva

14. Kanli Al (2009) Initial velocity model construction of seismic tomography in near-surface applications. J Appl Geophys 67:52-62. https://doi.org/10.1016/j.jappgeo.2008.09.005

15. Keceli A (2012) Soil parameters which can be determined with seismic velocities. Jeofizik 16:17-29. https://doi.org/11.a02/jeofi zik-1011-31

16. Khalil MH, Hanafy SM (2016) Geotechnical parameters from seismic measurements: two field examples from Egypt and Saudi Arabia. J Environ Eng Geophys 21:13-28. https://doi. org/10.2113/JEEG21.1.13

17. Leucci G, Greco F, Giorgi LD, Mauceri R (2006) Three-dimensional image of seismic refraction tomography and electrical resistivity tomography survey in the Castle of Occhiola. J Archaeol Sci 34:233-242. https://doi.org/10.1016/j.jas.2006.04.010

18. Maraio S, Bruno P, Testa G, Tedesco P, Izzo G (2014) Application of seismic refraction tomography to detect anthropogenic buried cavities in Province of Naples. GNGTS, Trieste, pp 90-94

19. Martínez-Pagán $P$, Navarro M, Pérez-Cuevas J, Alcalá FJ, GarcíaJerez A, Vidal Fr (2018) Shear-wave velocity structure from MASW and SPAC methods: the case of Adra town, SE Spain. Near Surf Geophys 16:356-371. https://doi.org/10.3997/18730604.2018012

20. Molina S, Navarro M, Martínez-Pagan P, Pérez-Cuevas J, Vidal F, Navarro D, Agea-Medina N (2018) Potential damage and losses in a repeat of the 1910 Adra (Southern Spain) earthquake. Nat Hazards 92:1547-1571. https://doi.org/10.1007/s1106 9-018-3263-6

21. Moustafa SS, Adel Mohamed ME, Abd El-Aal KA (2007) Applicability of near-surface seismic refraction technique to site characterization of South Marsa Matrouh and Sedi Abd El-Rahman. Western Desert, Egypt. J Appl Geophys 6(2):77-85

22. Raghu Kanth S, lyengar RN (2007) Estimation of seismic spectral acceleration in peninsular India. J Earth Syst Sci 116(3):199-214

23. Rucker ML (2000) Applying the seismic refraction technique to exploration for transportation facilities. AMEC Earth \& Environmental, Inc., Calgary, pp 1-18

24. Sarkar R, Dorji K (2019) Determination of the probabilities of landslide events-a case study of Bhutan. Hydrology 6:52

25. Sheehan RJ, Doll EW, Wayne AM (2005) An evaluation of methods and available software for seismic refraction tomography analysis. J Environ Eng Geophys 10:21-34

26. Sitharam TG, James N, Kolathayar S (2018) Comprehensive seismic zonation schemes for regions at different scales. Springer Berlin

27. Stewart J, Liu A, Choi Y (2003) Amplification factors for spectral acceleration in tectonically active regions. Bull Seismol Soc Am 93(1):332-352

28. Sultan Araffa SA, Atya MA, Mohamed AM, Gabala M, Zaher MA Soliman MM, Shaaban HM (2014) Subsurface investigation on 
Quarter 27 of May 15th city, Cairo, Egypt using electrical resistivity tomography and shallow seismic refraction techniques. J Astron Geophys 3:170-183

29. Thapa et al (2015) Report on technical feasibility study for the four critical landslides within the extended township of Phuentsholing. https://www.ungm.org/UNUser/Documents/Downl oadPublicDocument?docld=313634. Last accessed 14 Dec 2020

30. Uhlemann S, Hagedorn S, Dashwood B, Maurer H, Gunn D, Dijkstra D, Chambers J (2016) Landslide characterization using P and S-wave seismic refraction tomography-the importance of elastic moduli. J Appl Geophys 134:64-76

Publisher's Note Springer Nature remains neutral with regard to jurisdictional claims in published maps and institutional affiliations. 